\title{
Amycolatopsis thailandensis sp. nov., a poly(L-lactic acid)-degrading actinomycete, isolated from soil
}

\author{
Atchareeya Chomchoei, ${ }^{1}$ Wasu Pathom-aree, ${ }^{1}$ Akira Yokota, ${ }^{2}$ \\ Chartchai Kanongnuch $^{3}$ and Saisamorn Lumyong ${ }^{1}$ \\ ${ }^{1}$ Department of Biology, Faculty of Science, Chiang Mai University, Chiang Mai 50200, Thailand \\ ${ }^{2}$ Institute of Molecular and Cellular Bioresources, The University of Tokyo, Tokyo 113-0032, Japan \\ ${ }^{3}$ Department of Biotechnology, Faculty of Agro-Industry, Chiang Mai University, Chiang Mai 50200, \\ Thailand
}

Correspondence

Saisamorn Lumyong scboi009@chiangmai.ac.th

\begin{abstract}
A novel actinomycete that was capable of degrading poly(L-lactic acid), strain CMU-PLA07 ${ }^{\top}$, was isolated from soil in northern Thailand. Strain CMU-PLA07 ${ }^{\top}$ had biochemical, chemotaxonomic, morphological and physiological properties that were consistent with its classification in the genus Amycolatopsis. 16S rRNA gene sequence analysis showed that the isolate formed a phyletic line within the genus Amycolatopsis. Strain CMU-PLA07 ${ }^{\top}$ was most similar to Amycolatopsis coloradensis IMSNU $22096^{\top}$ (99.5\% 16S rRNA gene sequence similarity) and Amycolatopsis alba DSM $44262^{\top}$ (99.4\%). However, strain CMU-PLA07 ${ }^{\top}$ was distinguishable from the type strains of species of the genus Amycolatopsis on the basis of DNA-DNA relatedness and phenotypic data. Therefore, strain CMU-PLA07 ${ }^{\top}$ is considered to represent a novel species of the genus Amycolatopsis, for which the name Amycolatopsis thailandensis sp. nov. is proposed. The type strain is CMU-PLA07 ${ }^{\top}\left(=\mathrm{JCM} 16380^{\top}=\mathrm{BCC}^{3} 3279^{\top}\right)$.
\end{abstract}

Biodegradable plastics are increasingly considered to be the most promising alternative to disposable plastic. Poly (L-lactic acid) (PLA) is a biodegradable plastic that can be produced by fermentation of renewable resources. It is expected that PLA will replace plastics from petrochemicals (Tokiwa \& Calabia, 2006; Li et al., 2008). PLA-degrading actinomycetes were first reported by Pranamuda et al. (1997) and identified as members of the genus Amycolatopsis, which is well known for its high PLA-degrading activity. The taxonomy of the genus Amycolatopsis is based on chemotaxonomic characteristics and phylogenetic study of $16 \mathrm{~S}$ rRNA gene sequences (Lechevalier et al., 1986; Mertz \& Yao, 1993; Labeda, 1995; Lee et al., 2000; Lee, 2009). At the time of writing, the genus Amycolatopsis consisted of 38 recognized species and many novel species have been reported from various environmental sources (Bian et al., 2009; Lee, 2009). This study investigated the taxonomic position of the novel PLA-degrading strain CMU-PLA07 ${ }^{\mathrm{T}}$, a member of the genus Amycolatopsis.

Abbreviations: DAP, diaminopimelic acid; PLA, poly(L-lactic acid).

The GenBank/EMBL/DDBJ accession number for the 16S rRNA gene sequence of strain CMU-PLA07 ${ }^{\top}$ is FJ581021.

A supplementary figure and a supplementary table are available with the online version of this paper.
Strain CMU-PLA07 ${ }^{\mathrm{T}}$ was isolated from natural park soil in northern Thailand. A soil sample ( $1 \mathrm{~g}$ ) was suspended in $10 \mathrm{ml}$ basal medium [containing $0.4 \%\left(\mathrm{NH}_{4}\right)_{2} \mathrm{SO}_{4}, 0.2 \%$ $\mathrm{K}_{2} \mathrm{HPO}_{4}, 0.1 \% \mathrm{KH}_{2} \mathrm{PO}_{4}, 0.05 \% \mathrm{MgSO}_{4} .7 \mathrm{H}_{2} \mathrm{O}$ and $0.1 \%$ yeast extract] with a $25 \mathrm{mg}$ sample of $0.1 \%(\mathrm{w} / \mathrm{v})$ PLA film, as described by Tomita et al. (1999), and incubated at $30{ }^{\circ} \mathrm{C}$ with rotary shaking at 150 r.p.m. for 14 days. The enriched culture broth was spread onto $0.1 \%(\mathrm{w} / \mathrm{v})$ emulsified PLA agar and incubated at $30{ }^{\circ} \mathrm{C}$ for 14 days.

The cultural and morphological characteristics were observed on ISP media as described by Shirling \& Gottlieb (1966). The colours of aerial mycelium, substrate mycelium and soluble pigment were observed after incubation for 14 days at $30{ }^{\circ} \mathrm{C}$ using a NBS/IBCC colour chart (Mundie, 1995). The morphological features of the mycelium and spores were observed by light microscopy (BH-2; Olympus) and scanning electron microscopy (model JSM-5910; JEOL).

Bacterial biomass for chemotaxonomic studies was prepared by culturing the isolate in ISP 2 medium with rotary shaking at 150 r.p.m. at $27{ }^{\circ} \mathrm{C}$ for 4 days. Cells were harvested and then freeze-dried. The cell-wall diaminopimelic acid (DAP) isomers were examined by twodimensional TLC (Tokyo Kasei) as described by Harper \& Davis (1979) and by HPLC as described by Yokota et al. (1993). The cell-wall sugar composition was analysed by 
GLC. Sugars were converted into their alditol acetates by the method of Sawardeker et al. (1965). Chloroform solutions of the alditol acetate derivatives were injected into a Shimadzu GC-17A gas chromatograph equipped with an Rtx 2330 column $(0.32 \mathrm{~mm} \times 30 \mathrm{~m}$; temperature $\left.175-240{ }^{\circ} \mathrm{C}\right)$. Isoprenoid quinones were extracted with chloroform/methanol $(2: 1, \mathrm{v} / \mathrm{v})$ and purified by TLC using hexane/diethyl ether $(85: 15, \mathrm{v} / \mathrm{v})$ as the solvent and the menaquinone fraction was analysed by HPLC (Collins \& Jones, 1981). The cell-wall amino acid composition was determined by HPLC according to the methods of Schleifer \& Kandler (1972) and Harper \& Davis (1979). Cellular fatty acids were extracted according to the protocol of the MIDI system (Microbial ID). Peaks were automatically integrated and identified using the Microbial Identification software (Sasser, 1990). Polar lipids were analysed by twodimensional TLC (Minnikin et al., 1979). The DNA G +C content was determined by HPLC as described by Mesbah et al. (1989).

Phenotypic characterization was carried out using established methods. Growth with $0-9 \%(\mathrm{w} / \mathrm{v}) \mathrm{NaCl}$, at 5, 10, $17,25,30,37$ and $45{ }^{\circ} \mathrm{C}$ and at $\mathrm{pH} 4.0-11.0$ was tested on ISP 2. Carbohydrate utilization was investigated on ISP 9 at $30{ }^{\circ} \mathrm{C}$ for 14 days. Acid production from carbohydrates and degradation of casein, aesculin, starch, L-tyrosine and urea were examined using the method described by Gordon et al. (1974). Catalase activity was determined by assessing bubble production in $3 \%(\mathrm{v} / \mathrm{v}) \mathrm{H}_{2} \mathrm{O}_{2}$. Enzyme activity was determined using the API ZYM system (bioMérieux) according to the manufacturer's instructions.

Genomic DNA was prepared according to a modified cetyltrimethylammonium bromide method (Murray \&
Thompson, 1980). The 16S rRNA gene of strain CMUPLA07 ${ }^{\mathrm{T}}$ was amplified by PCR using the universal primers 27F (5'-AGAGTTTGATCMTGGCTCAG-3') and 1525R (5'-AAGGAGGTGWTCCARCC- $\left.3^{\prime}\right)$. The PCR products were purified using a Nucleospin Extract II PCR purification kit (Macherey-Nagel) and sequenced by Macrogen. The 16S rRNA gene sequence was compared with the sequences obtained from public databases and aligned using CLUSTAL_x (Thompson et al., 1997). Phylogenetic and molecular evolution analysis was conducted using MEGA version 4.0 (Tamura et al., 2007). Tree topologies were evaluated by bootstrap analysis with 1000 resamplings. DNA-DNA relatedness studies were carried out in duplicate with five replications between strain CMU$\mathrm{PLA}_{0}{ }^{\mathrm{T}}$ and its closest phylogenetic neighbours using photobiotin-labelled probes in microplate wells as described by Ezaki et al. (1989) and a multi-well plate reader (CytoFluoR; PerSeptive Biosystems).

The morphological characteristics of strain CMU-PLA07 ${ }^{\mathrm{T}}$ were typical for members of the genus Amycolatopsis. The isolate grew well on all ISP media tested and formed powdery circular colonies that were covered with white to pale yellow aerial mycelium on different ISP media. On ISP 2, 5 and 7 media, aerial mycelium was abundant, which fragmented into long strands and had smooth-surfaced conidia (see Supplementary Fig. S1, available in IJSEM Online). Substrate mycelium was yellowish brown and well developed on ISP $3,4,5$ and 7 media. No diffusible pigments were produced on any of the media tested.

The cell-wall hydrolysates contained meso-diaminopimelic acid (meso-DAP) and arabinose and galactose as major sugars (cell-wall type IV; Lechevalier \& Lechevalier, 1970).

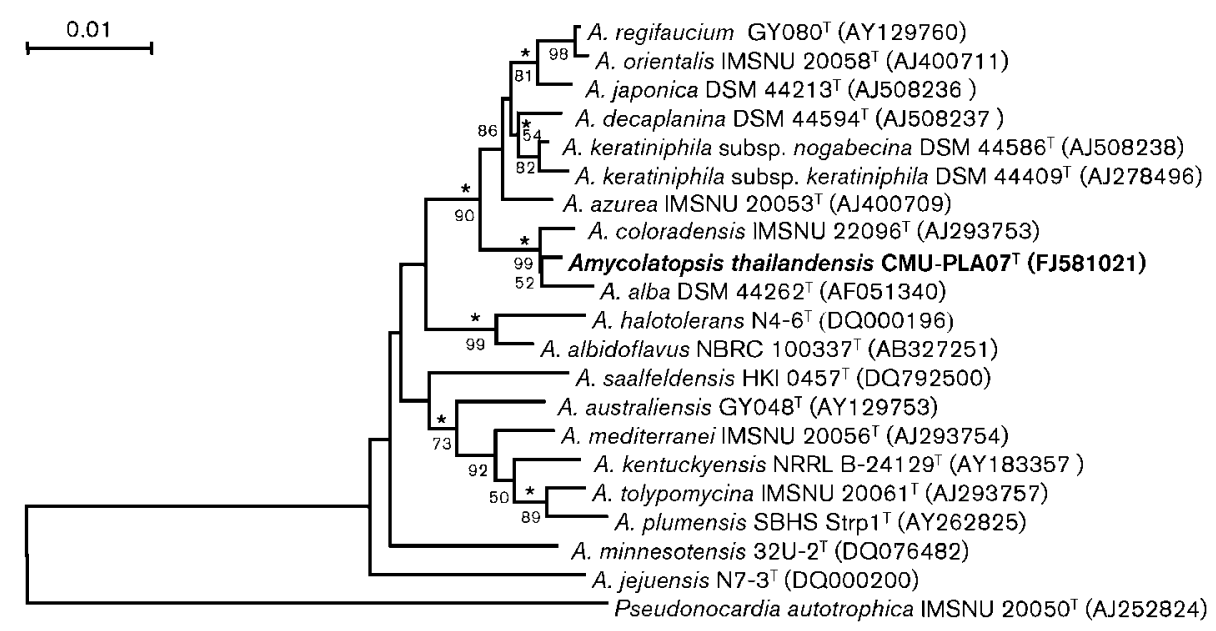

Fig. 1. Neighbour-joining phylogenetic tree based on 16S rRNA gene sequences showing the relationships between strain CMU-PLA07 ${ }^{\top}$ and related members of the genus Amycolatopsis. Bootstrap values $(>50)$ based on 1000 resamplings are shown at branch nodes. Asterisks indicate that the corresponding nodes were also found in trees generated with the minimumevolution and maximum-parsimony algorithms. Pseudonocardia autotrophica IMSNU $20050^{\top}$ was used as an outgroup. Bar, 0.01 substitutions per nucleotide position. 
The cell-wall amino acids were alanine, glutamate, mesoDAP and glycine. The menaquinone was $\mathrm{MK}-9\left(\mathrm{H}_{4}\right)$. The polar lipid pattern was composed of phosphatidylglycerol, diphosphatidylglycerol, phosphatidylethanolamine, phosphatidylinositol and phosphatidylmethylethylethanolamine. All of the chemotaxonomic properties of strain CMU-PLA07 ${ }^{\mathrm{T}}$ were consistent with those of the genus Amycolatopsis (Lechevalier et al., 1986; Henssen et al., 1987; Kim \& Goodfellow, 1999; Tan et al., 2006).

The fatty acid analysis was performed with strain CMUPLA0 $7^{\mathrm{T}}$ and its closest phylogenetic neighbours. The fatty acid profiles contained a mixture of saturated and branched-chain acids. The predominant fatty acids of strain CMU-PLA07 ${ }^{\mathrm{T}}$ were iso- $\mathrm{C}_{15: 0}$ (21.47\%), $\mathrm{C}_{16: 0}$ $(20.72 \%)$ and iso- $\mathrm{C}_{16: 0}(14.41 \%)$. Strain CMU-PLA07 ${ }^{\mathrm{T}}$ differed from Amycolatopsis coloradensis JCM $9869^{\mathrm{T}}$ and Amycolatopsis alba JCM $10030^{\mathrm{T}}$ by containing minor amounts of $\mathrm{C}_{16: 0}$ 9-methyl but not anteiso- $\mathrm{C}_{16: 0}$ or anteiso- $\mathrm{C}_{17: 0} 2-\mathrm{OH}$ (see Supplementary Table S1).

The neighbour-joining tree based on 16S rRNA gene sequences revealed that strain CMU-PLA0 $7^{\mathrm{T}}$ belonged to the genus Amycolatopsis and formed a clade with $A$. coloradensis IMSNU $22096^{\mathrm{T}}$ and A. alba DSM $44262^{\mathrm{T}}$, which was supported by a bootstrap value of $99 \%$ (Fig. 1). The minimum-evolution and maximum-parsimony algorithms resulted in trees with similar topologies. Strain CMU-PLA07 ${ }^{\mathrm{T}}$ was most closely related to A. coloradensis IMSNU $22096^{\mathrm{T}}$ (99.5\% 16S rRNA gene sequence similarity) and A. alba DSM $44262^{\mathrm{T}}(99.4 \%)$. Strain CMUPLA $07^{\mathrm{T}}$ displayed low DNA-DNA relatedness with $A$. coloradensis JCM $9869^{\mathrm{T}}$ and A. alba JCM $10030^{\mathrm{T}}(49 \pm 1.4$ and $45 \pm 2.8 \%$, respectively). Both values were significantly less than the $70 \%$ cut-off value recommended for the delineation of bacterial species by Wayne et al. (1987). Some members of the genus Amycolatopsis share high 16S rRNA gene sequence similarity but less than $70 \%$ DNADNA relatedness. For example, the type strains of Amycolatopsis lexingtonensis and Amycolatopsis pretoriensis share $99.9 \%$ 16S rRNA gene sequence similarity and $54.1 \%$ DNA-DNA relatedness (Labeda et al., 2003). Similarly, the type strains of Amycolatopsis methanolica and Amycolatopsis thermoflava share $99.8 \% 16 \mathrm{~S}$ rRNA gene sequence similarity and only $21 \%$ DNA-DNA relatedness (Chun et al., 1999). The DNA G+C content of strain CMU-PLA07 $^{\mathrm{T}}$ was $67 \mathrm{~mol} \%$.

The results of the physiological and biochemical characterization are given in the species description and the phenotypic characteristics that differentiated strain CMUPLA $07^{\mathrm{T}}$ from its closest phylogenetic neighbours, A. coloradensis JCM $9869^{\mathrm{T}}$ and A. alba JCM $10030^{\mathrm{T}}$, are given in Table 1. Strain CMU-PLA07 ${ }^{\mathrm{T}}$ differed from the reference strains in its ability to grow at $37^{\circ} \mathrm{C}$ and to produce acid from maltose and D-ribose.

On the basis of phenotypic, chemotaxonomic and genotypic characteristics, strain CMU-PLA07 ${ }^{\mathrm{T}}$ represents
Table 1. Phenotypic and biochemical characteristics of strain CMU-PLAO7 ${ }^{\top}$ and its closest phylogenetic neighbours

Strains: 1, CMU-PLA07 ${ }^{\mathrm{T}}$; 2, A. coloradensis JCM 9869 ${ }^{\mathrm{T}}$; 3, A. alba JCM $10030^{\mathrm{T}}$. +, Positive; $\mathrm{w}$, weakly positive; - , negative.

\begin{tabular}{|c|c|c|c|}
\hline Characteristic & 1 & 2 & 3 \\
\hline Production of diffusible pigments & - & + & - \\
\hline Nitrate reduction & + & + & - \\
\hline \multicolumn{4}{|l|}{ Growth at/in: } \\
\hline $37^{\circ} \mathrm{C}$ & + & - & - \\
\hline $7 \% \mathrm{NaCl}$ & + & - & + \\
\hline \multicolumn{4}{|l|}{ Utilization of: } \\
\hline Sucrose & - & $\mathrm{W}$ & + \\
\hline Raffinose & + & $\mathrm{W}$ & + \\
\hline Cellulose & - & - & + \\
\hline \multicolumn{4}{|l|}{ Degradation of: } \\
\hline Urea & + & - & + \\
\hline \multicolumn{4}{|l|}{ Acid production from: } \\
\hline D-Galactose & + & + & $\mathrm{w}$ \\
\hline Lactose & + & - & + \\
\hline Maltose & + & - & - \\
\hline Melibiose & + & - & $\mathrm{w}$ \\
\hline Raffinose & + & - & + \\
\hline D-Ribose & + & - & - \\
\hline L-Sorbose & - & $\mathrm{W}$ & - \\
\hline Trehalose & + & + & $\mathrm{w}$ \\
\hline \multicolumn{4}{|l|}{ Enzyme activity } \\
\hline Cystine arylamidase & $\mathrm{w}$ & + & + \\
\hline$\beta$-Galactosidase & - & - & + \\
\hline$\alpha$-Galactosidase & $\mathrm{w}$ & - & - \\
\hline Lipase (C14) & - & + & - \\
\hline Urease & + & - & + \\
\hline
\end{tabular}

a novel species of the genus Amycolatopsis, for which the name Amycolatopsis thailandensis sp. nov. is proposed.

\section{Description of Amycolatopsis thailandensis sp. nov.}

Amycolatopsis thailandensis (thai.land.en'sis. N.L. fem. adj. thailandensis pertaining to Thailand, the source of the soil from which the type strain was isolated).

Gram-positive, aerobic, non-motile and non-acid-fast actinomycete, which forms white colonies on ISP 2. Aerial mycelium is white to pale yellow with long fragmented strands of smooth-surfaced conidia. Substrate mycelium is yellowish brown. No diffusible pigment is produced. On ISP 2, grows at $\mathrm{pH}$ 5.0-11.0 (optimum $\mathrm{pH}$ 6.0-10.0), at $10-37{ }^{\circ} \mathrm{C}$ (optimum $25-37{ }^{\circ} \mathrm{C}$ ), but not at $45{ }^{\circ} \mathrm{C}$, and with $7 \%(\mathrm{w} / \mathrm{v}) \mathrm{NaCl}$. Cell-wall hydrolysates contain meso-DAP, arabinose and galactose. The menaquinone is $\mathrm{MK}-9\left(\mathrm{H}_{4}\right)$. The polar lipids are phosphatidylglycerol, diphosphatidylglycerol, phosphatidylethanolamine, phosphatidylinositol and phosphatidylmethylethylethanolamine. The major fatty acids $(>10 \%)$ are iso- $\mathrm{C}_{15: 0}, \mathrm{C}_{16: 0}$ and iso- $\mathrm{C}_{16: 0}$. Arabinose, fructose, glucose, inositol, mannitol, raffinose and xylose are utilized as sole carbon sources, 
but not cellulose, rhamnose or sucrose. Nitrate is reduced to nitrite and gelatin is hydrolysed. Acid is produced from cellobiose, D-fructose, D-galactose, D-glucose, inositol, lactose, maltose, D-mannitol, D-mannose, melibiose, raffinose, D-ribose, trehalose and D-xylose, but not from L-arabinose, L-rhamnose, D-sorbitol or L-sorbose. Casein, aesculin, starch, L-tyrosine and urea are degraded, but not adenine. Positive for acid phosphatase, $N$-acetyl- $\beta$-glucosamidase, alkaline phosphatase, catalase, esterase, esterase lipase (C8), $\alpha$-glucosidase, $\beta$-glucosidase, leucine arylamidase, naphtholAS-BI-phosphohydrolase, pyrazinamidase, pyrrolidonyl arylamidase, urease and valine arylamidase, weakly positive for $\alpha$-chymotrypsin, cystine arylamidase, $\alpha$-galactosidase and trypsin, but negative for $\alpha$-fucosidase, $\beta$-galactosidase, $\beta$-glucosidase, $\beta$-glucuronidase, lipase (C14) and $\alpha$-mannosidase.

The type strain, CMU-PLA07 ${ }^{\mathrm{T}}\left(=\mathrm{JCM} 16380^{\mathrm{T}}=\right.$ BCC $\left.38279^{\mathrm{T}}\right)$, was isolated from soil in northern Thailand and is able to degrade poly(L-lactic acid). The DNA G $+\mathrm{C}$ content of the type strain is $67 \mathrm{~mol} \%$.

\section{Acknowledgements}

This work is supported by a grant under the programme Strategic Scholarships for Frontier Research Network for the Joint PhD Program Thai Doctoral degree from the Thailand Higher Education Commission, Targent Research, National Research University programmes and Graduate School of Chiang Mai University.

\section{References}

Bian, J., Li, Y., Wang, J., Song, F.-H., Liu, M., Dai, H.-Q., Ren, B., Gao, H., $\mathrm{Hu}, \mathbf{X}$. \& other authors (2009). Amycolatopsis marina sp. nov., an actinomycete isolated from an ocean sediment. Int J Syst Evol Microbiol 59, 477-481.

Chun, J., Kim, S. B., Oh, Y. K., Seong, C.-N., Lee, D.-H., Bae, K. S., Lee, K.-J., Kang, S.-O., Hah, Y. C. \& Goodfellow, M. (1999). Amycolatopsis thermoflava sp. nov., a novel soil actinomycete from Hainan Island, China. Int J Syst Bacteriol 49, 1369-1373.

Collins, M. D. \& Jones, D. (1981). A note on the separation of natural mixtures of bacterial ubiquinones using reverse-phase partition thinlayer chromatography and high performance liquid chromatography. J Appl Bacteriol 51, 129-134.

Ezaki, T., Hashimoto, Y. \& Yabuuchi, E. (1989). Fluorometric deoxyribonucleic acid-deoxyribonucleic acid hybridization in microdilution wells as an alternative to membrane filter hybridization in which radioisotopes are used to determine genetic relatedness among bacterial strains. Int J Syst Bacteriol 39, 224-229.

Gordon, R. E., Barnett, D. A., Handerhan, J. E. \& Pang, C. (1974). Nocardia coeliaca, Nocardia autotrophica, and the nocardin strain. Int J Syst Bacteriol 24, 54-63.

Harper, J. J. \& Davis, G. H. G. (1979). Two-dimensional thin-layer chromatography for amino acid analysis of bacterial cell walls. Int $J$ Syst Bacteriol 29, 56-58.

Henssen, A., Kothe, H. W. \& Kroppenstedt, R. M. (1987). Transfer of Pseudonocardia azurea and "Pseudonocardia fastidiosa" to the genus Amycolatopsis, with emended species description. Int J Syst Bacteriol 37, 292-295.
Kim, S. B. \& Goodfellow, M. (1999). Reclassification of Amycolatopsis rugosa Lechevalier et al. 1986 as Prauserella rugosa gen. nov., comb. nov. Int J Syst Bacteriol 49, 507-512.

Labeda, D. P. (1995). Amycolatopsis coloradensis sp. nov., the avoparcin (LL-AV290)-producing strain. Int J Syst Bacteriol 45, 124-127.

Labeda, D. P., Donahue, J. M., Williams, N. M., Sells, S. F. \& Henton, M. M. (2003). Amycolatopsis kentuckyensis sp. nov., Amycolatopsis lexingtonensis sp. nov. and Amycolatopsis pretoriensis sp. nov., isolated from equine placentas. Int J Syst Evol Microbiol 53, 1601-1605.

Lechevalier, M. P. \& Lechevalier, H. A. (1970). Chemical composition as a criterion in the classification of aerobic actinomycetes. Int J Syst Bacteriol 20, 435-443.

Lechevalier, M. P., Prauser, H., Labeda, D. P. \& Ruan, J. S. (1986). Two new genera of nocardioform actinomycetes: Amycolata gen. nov. and Amycolatopsis gen. nov. Int J Syst Bacteriol 36, 29-37.

Lee, S. D. (2009). Amycolatopsis ultiminotia sp. nov., isolated from rhizosphere soil, and emended description of the genus Amycolatopsis. Int J Syst Evol Microbiol 59, 1401-1404.

Lee, S. D., Kim, E. S. \& Hah, Y. C. (2000). Phylogenetic analysis of the genera Pseudonocardia and Actinobispora based on $16 \mathrm{~S}$ ribosomal DNA sequences. FEMS Microbiol Lett 182, 125-129.

Li, F., Wang, S., Liu, W. \& Chen, G. (2008). Purification and characterization of poly(L-lactic acid)-degrading enzymes from Amycolatopsis orientalis ssp. orientalis. FEMS Microbiol Lett 282, 5258.

Mertz, F. P. \& Yao, R. C. (1993). Amycolatopsis alba sp. nov., isolated from soil. Int J Syst Bacteriol 43, 715-720.

Mesbah, M., Premachandran, U. \& Whitman, W. B. (1989). Precise measurement of the $\mathrm{G}+\mathrm{C}$ content of deoxyribonucleic acid by high-performance liquid chromatography. Int J Syst Bacteriol 39, 159-167.

Minnikin, D. E., Collins, M. D. \& Goodfellow, M. (1979). Fatty acid and polar lipid composition in the classification of Cellulomonas, Oerskovia and related taxa. J Appl Bacteriol 47, 87-95.

Mundie, D. A. (1995). The NBS/ISCC Color System. Pittsburgh, PA: Polymath Systems 535.6 dc-20 (http://www.tx4.us/nbs-iscc.htm, accessed February 2011).

Murray, M. G. \& Thompson, W. F. (1980). Rapid isolation of high molecular weight plant DNA. Nucleic Acids Res 8, 4321-4326.

Pranamuda, H., Tokiwa, Y. \& Tanaka, H. (1997). Polylactide degradation by an Amycolatopsis sp. Appl Environ Microbiol 63, 1637-1640.

Sasser, M. (1990). Identification of bacteria by gas chromatography of cellular fatty acids, MIDI Technical Note, 101. Newark, DE: MIDI Inc.

Sawardeker, J. S., Sloneker, J. H. \& Jeanes, A. (1965). Quantitative determination of monosaccharides as their alditol acetates by gas liquid chromatography. Anal Chem 37, 1602-1604.

Schleifer, K. H. \& Kandler, O. (1972). Peptidoglycan types of bacterial cell walls and their taxonomic implications. Bacteriol Rev 36, 407477.

Shirling, E. B. \& Gottlieb, D. (1966). Methods for characterization of Streptomyces species. Int J Syst Bacteriol 16, 313-340.

Tamura, K., Dudley, J., Nei, M. \& Kumar, S. (2007). MEGA4: Molecular evolutionary genetics analysis (MEGA) software version 4.0. Mol Biol Evol 24, 1596-1599.

Tan, G. Y. A., Robinson, S., Lacey, E. \& Goodfellow, M. (2006). Amycolatopsis australiensis sp. nov., an actinomycete isolated from arid soils. Int J Syst Evol Microbiol 56, 2297-2301. 
Thompson, J. D., Gibson, T. J., Plewniak, F., Jeanmougin, F. \& Higgins, D. G. (1997). The CLUSTAL_X windows interface: flexible strategies for multiple sequence alignment aided by quality analysis tools. Nucleic Acids Res 25, 4876-4882.

Tokiwa, Y. \& Calabia, B. P. (2006). Biodegradability and biodegradation of poly(lactide). Appl Microbiol Biotechnol 72, 244-251.

Tomita, K., Kuroki, Y. \& Nagai, K. (1999). Isolation of thermophiles degrading poly(L-lactic acid). J Biosci Bioeng 87, 752-755.
Wayne, L. G., Brenner, D. J., Colwell, R. R., Grimont, P. A. D., Kandler, O., Krichevsky, M. I., Moore, L. H., Moore, W. E. C., Murray, R. G. E. \& other authors (1987). International Committee on Systematic Bacteriology. Report of the ad hoc committee on reconciliation of approaches to bacterial systematics. Int J Syst Bacteriol 37, 463-464.

Yokota, A., Tamura, T., Nishii, T. \& Hasegawa, T. (1993). Kineococcus aurantiacus gen. nov., sp. nov., a new aerobic gram-positive, motile coccus with meso-diaminopimelic acid and arabinogalactan in the cell wall. Int J Syst Bacteriol 43, 52-57. 